\title{
AN INITIAL STUDY ON ARTHROPOD SUCCESSION ON EXPOSED HUMAN TISSUES IN ASSIUT, EGYPT
}

\author{
$\mathcal{B Y}$ \\ Lamia A. A. Galal, Saly Y. Abd-El-hameed*, \\ Rasha A. H. Attia and Doaa A. Uonis \\ Departments of Medical Parasitology and Forensic Medicine and Clinical Toxicology*, \\ Faculty of Medicine, Assiut University.
}

\begin{abstract}
Forensic entomology uses different stages of arthropods as an entomological evidence at death scene to estimate the postmortem interval (PMI) using either succession waves or maggot age and its development. The arthropod succession patterns are greatly affected by temperature and humidity. Their development rate also differs physiologically depending on their geographical origin. Therefore the knowledge of local fauna is very useful in forensic investigations. Data from other areas having both different environmental and faunal characteristics might provide insufficient degree of accuracy. The aim of this study is to document arthropod fauna and succession pattern in relation to decomposition stages of human left over parts, in Assiut, during spring-summer season. The experiment was performed during springsummer season. Human left over parts from orthopedic theatre were used. Specimens were placed in a box, floored with soil and protected with scavenger-exclusion cage and placed upon the roof of Faculty of Medicine, Assiut University Campus. Inspection of the specimens was done and at each visit flying insects, larvae and crawling species were collected. Immature stages were reared in the laboratory till adult stage in order to be identified. The results of main insect groups were discussed in relation to decomposition stages. Many insect species were identified and the following orders were represented: Diptera (Calliphoridae, Sarcophagidae, and Muscidae), Coleoptera (Dermestidae) and Hymenoptera (Formicidae). Preliminary documentation of entomofauna of Assiut city (arid, urban environment) revealed that Diptera was the predominant group followed by Coleoptera. Chrysomya albiceps was the predominant species and the only Calliphora species found to colonize the human tissues.
\end{abstract}

Keywords: Forensic Entomology, Insect Succession, Human Left Over Parts.

\section{INTRODUCTION}

Forensic entomology is the science, which applies knowledge of insects and other arthropods to civil proceedings and criminal trials (Turchetto and Vanin, 2004). Each group of arthropods plays a given role in different stages of decompo- 
sition of organic matter, a particular group being defined by the feeding habits of its members. The usual classification of sacrosaprophagous fauna divides them into five distinct ecological groups; necrophages which arrive first and eat from the corpse; necrophiles, which feed on necrophages inside the corpse by predation or parasitism; omnivores, which feed on the corpse and associated fauna; opportunists, which use the corpse as refuge, source of heat, etc. and accidentals, whose presence is due to chance. In general, necrophages, necrophils and omnivores are the most important for forensic purpose (Arnaldos et al., 2005).

The main aim of forensic entomology is to establish the post mortem interval (PMI) or time elapsed since death by using information on the insects that visit the corpse. There are two methods; first using the developmental stages of flies found on corpse as they first lay eggs on the body (Catts, 1990). A second method uses the succession patterns of carrion- arthropods, the type and composition of fauna change in a predictable pattern as decomposition progresses through different stages (Schoenlly et al., 1996). The rate of carrion decomposition and arthropod succession are influenced by many factors, the more important are temperature, humidity, rainfall and abundance of insects (Tantawi et al., 1996). The pattern of arthropod succession is specific to the loca- tion and environmental conditions in which a carcass occurs. Studies on carrion arthropods had been conducted in several regions of the world to determine the species composition and succession patterns (Tabor et al., 2005).

However, there are no published data on the forensically important insects in Assiut city, Egypt.

The aim of this study is to document the entomofauna and its succession pattern in relation to the decomposition stages of human tissue during spring-summer season.

\section{MATERIAL AND METHODS}

Site description: The study was carried out in Assiut city Capital of Assiut Governorate, located $375 \mathrm{~km}$ South to Cairo. Assiut Governorate is known to occur in the Great Desert region. Assiut city, geographical position ranges from longitude $30^{\circ} 45^{\prime}$ to $31^{\circ} 27^{\prime}$ east and from latitude 26 o45' to 27 o45' north (Moatamed, 2005). The study was located in Assiut University campus (310 09' E, 27o 11' N) about 2 km north to city centre. Elevation of the study site was 39 meter above the sea level and was 15 meter above the ground level. Coordinates and elevation of the study site were taken on the day of placement with handheld GPS unit (e-trex vista, Garmin corp., Olathe, KS) . 
The average maximum temperature for spring and summer in Assiut are respectively $31.3^{\circ} \mathrm{C}$ and $37^{\circ} \mathrm{C}$ while the average relative humidity is for spring $28 \%$ and $33 \%$ for summer (Moatamed, 2005).

Daily weather data (mean of maximum and minimum) temperature and relative humidity were acquired from the Egyptian Meteorological Authority, Assiut station in the university campus.

Experiments: Two experiments were performed during spring-summer season. First experiment included two specimens and the second experiment included three specimens of human leftover parts (HLOP). HLOP were provided from orthopedic surgical theatre after tumor mass excision (osteosarcoma excised from the lower thigh or upper leg). Each specimen includes skin, muscles and bone. They were weighting about $2-2.5 \mathrm{~kg}$. They were exposed on soil-floored boxes protected by vertebrate scavenger-exclusion cage made of stainless steal (100x $80 \mathrm{~cm}$ and 15 $\mathrm{cm}$ height). The first experiment was initiated on $5^{\text {th }}$ May 2007 and the second on $13^{\text {th }}$ May 2007. The second experiment lasted until skeletalization occur. Observations were recorded on the physical changes of the HLOP over time (color, degree of swelling fluid oozing, size of the remaining part, ect...) every visit. After the end of the experiments the rest of the specimens were buried according to Islamic rules.

On-site procedure: Inspection of the HLOP was done every day during early decomposition stages at $10 \mathrm{am}$ and $6 \mathrm{pm}$ then every two days in later stages. At each visit larvae and crawling species were collected with a forceps. The specimens were gently lifted to sample the fauna underneath searching for post feeding larvae and pupae. They were also collected up to 2 meter around the experiment box. Flying insects were captured by an aerial net before the carcass was moved. Collected adult flies, beetles and other insects were killed by ethyl acetate and placed in numbered and dated vials containing $70 \%$ alcohol until further identification (Centeno et al., 2002). The collected arthropod larvae and pupae were divided into two groups: the first group was killed in hot water then placed in vials containing $70 \%$ alcohol for further identification. Then the preserved larvae were prepared according to Lee et al (2004). The second group was kept alive and reared in the laboratory by transferring them into dry glass jar with small pieces of cow liver on a layer of saw dust. Dry saw dust was added to larvae to pupate (Tantawi et al., 1996). Larvae and adults were determined according to specific keys (Greenberg, 1971; Mosallam, 1980; Shaumar et al., 1989; Wells et al., 1999). 


\section{RESULTS}

\section{The first experiment results:}

The experiment had started on the $5^{\text {th }}$ May 2007, the specimens showed dryness of the tissues, dark brown coloration, and hardness of skin and underlying tissues.

All along their observation for about two weeks there were no insects seen colonizing the specimens at any stage of their development; adults, eggs or larvae. During this period the relative humidity recorded its lowest level and highest air temperature (Figs. $1 \& 2$ ).

\section{The second experiment results:}

A total of 9 genera (Table 1) of insects representing three orders and six families are found to coexist in different decomposition stages of the human left over parts. (Tables 2 \& 3).

Decomposition stages are classified according to Reed (1958).

1. Fresh stage of decomposition: It begins at 13-14 May from day 1-2 of the experiment (one day duration).

This stage begins at the moment when the specimens were excised and installed in the experiment box and continues until bloating is first evident. There were neither gross morphological changes nor odor of decay. Adult dipteran flies were catched while visiting the HLOP. Calliphoridae represented by Chrysomya albiceps (Fig. 3) and few Sarcophagidae represented by Sarcophaga carnaria and Wolhfahrtia. It was noticed that Calliphoridae were dominating over Sarcophagidae. Hymenoptera of family Formicidae (large and small sized adults) of an unidentified species are found wandering over the specimens.

\section{Bloated stage of decomposition: It} begins at 15-23 May from day 3-11 of the experiment (8 days duration).

It begins with slight swelling of the specimens, discoloration and odor of decay became noticeable. Small amount of decomposition fluids were oozing beneath the specimens. Flying adults were still frequenting the HLOP. Sarcophagidae (Tables 2 \& 3) had increased until to be scarce at the end of the stage, in addition to colored adult flies (Table 2) and adults Musca domestica. Larvae of variable sizes had appeared; they were collected and reared in the laboratory. After 10-12 days they emerged as adults Chrysomya albiceps, Sarcophaga carnaria, Wolhfahrtia beside two colored flies of unidentified species. Some larvae were detected crawling out, one meter away from the box. They were reared and the emerging adults were identified as Sarcophaga carnaria. At the $6^{\text {th }}$ day, adult beetles of the family Dermestidae were observed. Ants of unidentified 
species still detected and continued till the end of decay stage.

3. Decay stage of decomposition: It begins at 24 May- 13 June from day 12-32 of the experiment (20 days duration).

This stage was characterized by the release of gases and deflation of the specimens. After nine days of adult beetles appearance, beetles larvae started to colonize the specimens. They were found in great abundance among the muscular mass and bones and increased in number vigorously. Rearing of these larvae yielded in the adult Dermestes species after 15-18 days. Numerous adults Dermestes species were detected under the specimens and around them in the soil (Table 3).

Only large dipteran larvae were found, they were reared and identified as Chrysomya albiceps adults. Morphologically different pupae were detected. Smooth surfaced light brown pupae were found on the edge of the box buried in the soil. Rough surfaced dark brown pupae were under the specimens while some others were buried in the soil. Rearing of these pupae revealed Sarcophaga carnaria, Wolhfahrtia species and Chrysomya albiceps (from rough surfaced pupae) after 4-7 days.

4. Dry stage of decomposition : It begins at 14 June till the end of the experi- ment at 31 July from day 33-80 of the experiment (47 days duration).

It is the final stage at which most of the fleshy tissue disappeared. The odor started to fade and the specimens consisted of only dry skin and bone. Later after decaying of all the soft tissues the skeletalization occurred.

In the first half of this stage, only larvae of beetle's and their larval exuviae (skin) were detected and collected. Rearing of the larvae yielded adult Dermestes species. Many dipteran's pupae and empty pupal cases were found all along this stage.

\section{DISCUSSION}

During the interval of $5^{\text {th }}$ May and $31^{\text {st }}$ July 2007 observation of the two experiments yielded significant information concerning the sequence and composition of the local HLOP visiting fauna during the spring summer season as well as the duration of decay rates in an urban arid region like Assiut city.

In the first experiment, which had started on $5^{\text {th }}$ May there was no colonization of any insects on the specimens: they got mummified (dry, shrunken and dark color). The mean air temperature during this week was $38.5^{\circ} \mathrm{C} \pm 3.8$ and humidity of $21 \%$ (Fig 1 \& 2). This result is in accor- 
dance with Greenberg and Kunich (2002). They labeled these cases as 'no fly cases' due to complete absence of flies and their immature stages. They believed that it's due to consequence of various factors such as extreme temperature and diversity of the cause of death. Introna and Campobasso (2000) stated that diptera do not oviposit on dehydrated or mummified tissue, as eggs and larvae need moisture for successful development.

The second experiment that started on $13^{\text {th }}$ May, the duration of each stage of decomposition was compared with other studies in the same season. In this study the fresh stage took only one day as noticed by Tantawi et al., (1996) and Aggarwal (2005) but shorter than Grassberger and Frank (2004) which was 2 days. The present bloated stage was 8 days which is longer than that observed by Tantawi et al.,(1996) but similar to Aggarwal (2005) and shorter than Grassberger and Frank (2004).

The bloated stage period is more dependable on the number of larvae infesting the carrion (Tantawi et al., 1996). The prolonged bloated stage of the current study might be due relative low diversity of their invading larvae. The present decay stage was more prolonged than that observed by others (Tantawi et al., 1996; Grassberger and Frank, 2004) and similar to Aggarwal (2005). This may be attribut- ed to the fact that the left over parts used did not contain intestine from which putrefactive bacteria originated. The muscles were the main constituent of the specimens which is made of protein that is under the bacterial action undergoes putrefaction and produce decomposition by products. Marchenko (2001) stated that the duration of individual stages of biological decay in the cadaver is considerably affected by meteorological factors. The duration of the $1^{\text {st }}, 3^{\text {rd }}$ and $4^{\text {th }}$ stages were found to be inversely proportional to the total radiation, air, ground surface temperature and solar radiation period. The relative air humidity is directly proportional to the $3^{\text {rd }}$ and $4^{\text {th }}$ stages but has no pronounced effect on the $2^{\text {nd }}$ stage.

Habitat, high temperatures with low relative humidity and size of the carrion played a great role in altering the diversity of carrion-breeding arthropods in the present study. In the present study nine genera were found to coexist (Table 1). Tomberlin and Adler (1988) found only 5 species of calliphorid, attributing this poverty to the habitat (exposed plowed field). Hwang and Turner (2004) collected the lowest total species richness (5 species) from a roof site in London. Similarly, the present habitat was on a roof 15 meter above the ground level. Such height position allowed smaller flying dipterans like Lucilia sp to be more effectively isolated as they do not have the higher metabolic 
rate as present in bigger Calliphorid or Sarcophagid (Von Aesh et al., 2003). In comparison to other studies done in Egypt by Hegazi et al. (1991) and Tantawi et al. (1996) performed under different habitat conditions; the diversity number was relatively higher in the respective season. Although, the collected arthropods species of Tantawi et al. (1996) still less in diversity in spring and summer season than other studies (Reed, 1958; Rodriguez; Lord and Burger, 1984; Arnaldos et al., 2004) in the similar seasons. Such contrast agrees with the present study and the Chittaro et al. (2005) work where they collected only 4-5 species during the famous hot summer wave of 2003. Therefore we could assume that the high temperature, which has been also recorded in the current study (Fig. 1), had accelerated the decomposition process, meaning that the carrion is reduced to bones in a shorter time period leading to rapid depletion of food resource and reduction of arthropod colonization time. Chittaro et al. (2005) assumed that this food shortage had also implied a very low reproduction, consequently reducing drastically blowflies' population.

The small size of the carrion leads to its rapid consumption by its early invaders giving no chance to later colonizers. This met with the low diversity observed by Tomberlin and Adler (1988) and with the present small carrion. Moreover, the human left over parts used in the current study retained less moisture (skin, muscles and bone) than other study (Iloba and Fawole, 2006) by which reducing its attractiveness. In general, Egypt has limited species richness (Larsen, 1989).

The succession of arthropod fauna observed on the carrion of the present study follow the same general pattern found in both tropical and temperate areas: rapid invasion of specimens by adult Diptera (calliphorids and sarcophagids) and ants. It was followed by the appearance of dipterous larvae and adult coleopterans during which the arthropod diversity reaches its maximum, then the marked decrease in arthropod richness and their dispersal from the carrion in the last stage of decomposition. (Table 2) which is in agreement with the views of Schoenly and Reid (1987) and Tantawi et al. (1996). The overwhelming majority of the insects were the flies and beetles, which formed a complex food web within the carrion.

Blowflies are attracted to human corpses within minutes (Nuorteva, 1977; Erzinclioglu, 1983; Erzinclioglu, 1996). They came up from their birth place over great distance to reach up their lay down places (Macleod and Donelly, 1963). They detect carcasses primarily by odor, but the attractiveness varies with the degree of decomposition (Nuorteva, 1977). 
Chrysomya albiceps one of the calliphorids detected in this study is a wellknown hemisynanthropic fly and generally described as a tropical and subtropical species (Hall and Smith, 1993). Chrysomya albiceps had been mentioned to occur in Egypt as one of the most important carrion breeding fly by Omar (1995), Tantawi et al. (1996), Adham et al. (2001) and Attia (2002).

Chrysomya albiceps adults were found on the carrion as soon as fresh stage. Similar observation was documented by Tantawi et al. (1996) in contrast to Grassberger and Frank (2004) and Arnaldos et al. (2005) where they were found only in the bloated stage. Chrysomya albiceps was the dominant dipteran fly in the current study as it was present all along the decomposition stages in its different developmental stages. Similar domination was stated by Grassberger and Frank (2004). Hanski (1987 a, b) observed that sarcophagid females have less fecundity than oviparous calliphorid female beside they don't deposit their larvae on one carcass unlike the oviparous calliphorid. Chrysomya albiceps larvae is known to have predatory activity on larvae of other Diptera and themselves as stated by Omar (1995), Tantawi et al. (1996) Bartholo et al. (2002) and Grassberger and Frank (2004). Therefore, it was the only larvae collected during the decay stage. Chrysomya albiceps is not recommended to be used as biogeaographic indicator in our country due to its wide distribution over Egypt (Tantawi et al., 1996; Hegazi et al., 1991; Omar, 1995; Adham et al., 2001; Attia, 2002) but still one of the reliable fly in estimation of PMI.

Sarcophagidae in this study were represented by Sarcophaga carnaria and Wolhfahrtia sp. Sarcophaga carnaria adults were captured early as the fresh stage. (Table 2). Their larvae were reared and emerged as adults. Sarcophaga carnaria was recorded in Assiut by Attia (2002) in spring and summer. In Alexendria neither Hegazi et al. (1991) nor Tantawi et al. (1996) found it as carrion breeding sarcophagid in any of the studied season, although they found other Sarcophaga sp.

Wolhfahrtia sp. adults were emerged from reared larvae and pupae in spring season unlike Tantawi et al. (1996) Wolhfahrtia adults were absent in spring and present in summer. This variation in season activity might be due to great climatic differences between Assiut (Moatamed, 2005) and Alexandria in spring and summer seasons.

The flies sequencing was not established in this study according to Fuller (1934); O'Flynn and Moorhouse (1979); Braack (1981) and Tullis and Goff (1987) stated that Calliphorinae are primary species invaders and Chrysominae are secon- 
dary one, whenever they co-exist and this match with the observation done by Tantawi et al. (1996). But, in the current study Calliphora species was absent, only Chrysomya albiceps as one of the members of subfamily Chrysomyinea was captured with Sarcophaga carnaria during first day the visit. Therefore, on the opposite, Payne (1965); Early and Goff (1986) stated that flesh flies are primary invaders of carrion in warmer temperate and tropical regions. Sarcophagidae was also found to precede Chrysomya rufifacies in succession by Greenberg and Wells (1998). The current study had no explanation for such observations; therefore more investigations are needed to be performed under similar conditions.

The order Coleoptera is the largest order of insects; the beetle fauna of corpse has received adequate attention during studies though its true assessment as forensic indicators, as some authors (Greenberg and Wells 1998; Bharti; Singh, 2003) used Dermestes maculates.

During the present study, beetles belonging to one genera were collected, namely, Dermestes species. Adults have been observed at $6^{\text {th }}$ day of decomposition till the first half of the dry stage and their larvae appeared early as day 15 and remain until late dry stage. This observation was in agreement with Tantawi et al.,
(1996) and Arnaldos et al., (2005). On the other hand, Rodriguez and Bass (1983) and Early and Goff (1986) studies, observed that Dermestidae were confined to later stages of decomposition and especially the dry stage. While Grassberger and Frank (2004) detected adult Dermestes maculates at day 19 of decomposition and their larvae don't appear until the day 55 of decomposition

During the present study, Coleoptera was the second dominant insect order following Diptera. Dermestes sp occupied most of the decomposition stages represented by many of its developmental stages e.g; adults, larvae, pupae and larva exuviae given the scarcity of faunistic studies of the sarcosaprophagous community in Egypt (Hegazi et al., 1991; Tantawi et al., 1996; Adham et al., 2001). More studies should be carried out in different geogra-phical situations and different habitats to confirm the present study preliminary observations. Thus, it will provide information on possible variations, in the qualitative composition of the community fauna.

The present study is just an initial study to document the visiting fauna in our locality in spring- summer seasons. Further studies in our locality are needed on the development curve of these fauna, the visiting fauna in au- 
tumn- winter seasons and changing the site of the experiment.

In conclusion the obtained information could constitute a useful data base for both forensic entomology investigations and in medical field in cases of myiasis.

\section{Acknowledgment :}

We thank Prof. B. Greenberg (University of Illinois, Chicago, USA) for his scientific guidance. The staff members of Orthopedics department, Assiut University Hospital for supplying us with the specimens. 
Table (1) : List of the arthropods collected from the human left over parts in Assiut city, during spring-summer season.

\begin{tabular}{|l|l|l|}
\hline \multicolumn{1}{|c|}{ Order } & \multicolumn{1}{|c|}{ Family } & \multicolumn{1}{c|}{ Genus and species } \\
\hline Diptera (true flies) & Calliphoridae & Chrysomya albiceps \\
& Unidentified species \\
Unidentified species & Sarcophagidae & Solhfahrtia sp \\
Coleoptera (beetles) & Muscidae & Musca domestica \\
Hymenoptera & Dermestidae & Dermestes sp \\
& Unidentified & Unidentified sp \\
& Formicidae & Unidentified species \\
\hline
\end{tabular}


Table (2) : Succession of insect species collected from human left over parts in Assiut City during spring-summer season 2007.

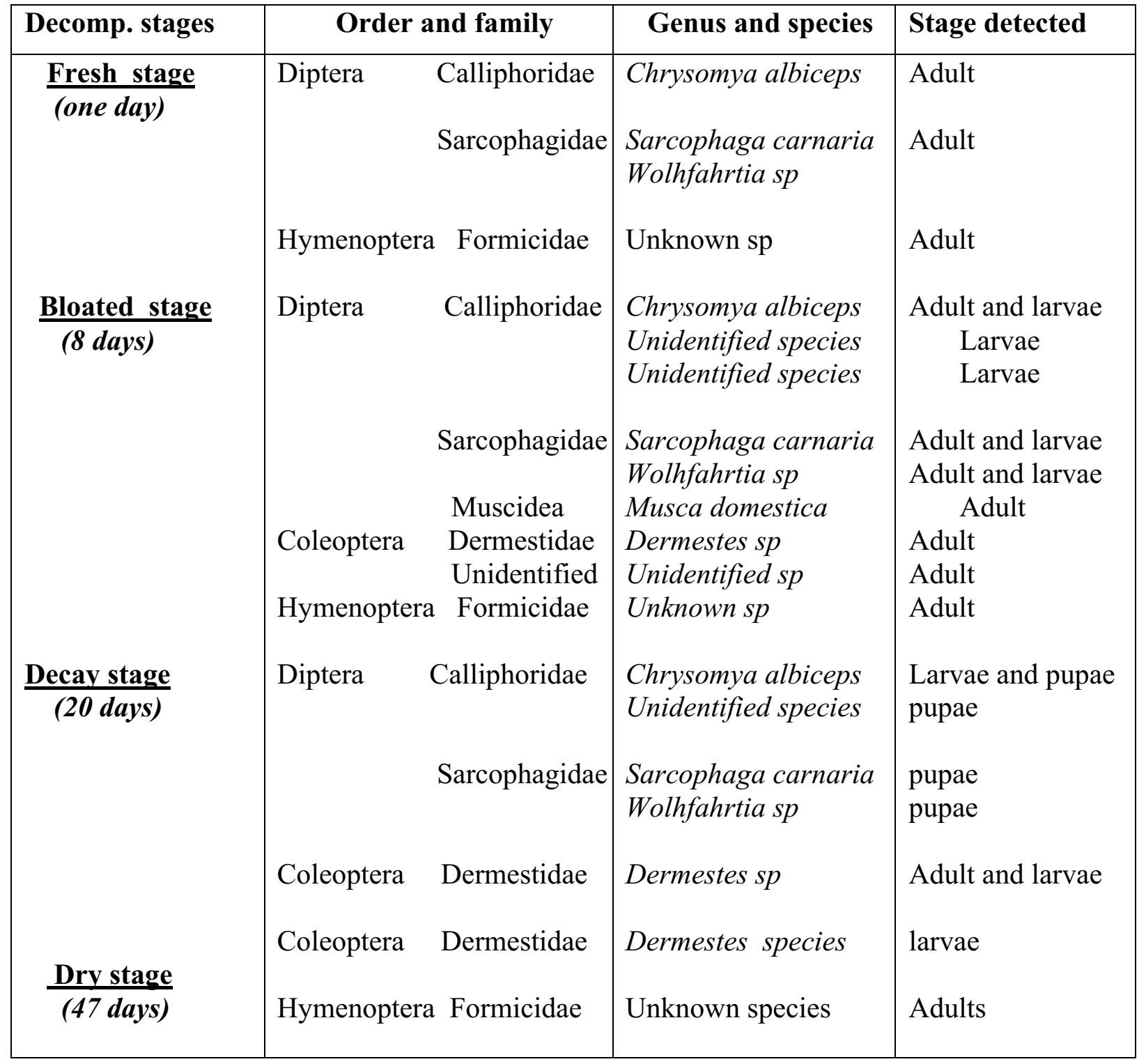

Decomp. : Decomposition 
Table (3) : Numbers and percentages of the arthropods collected from human left over parts in Assiut City during spring-summer season 2007.

\begin{tabular}{|c|c|c|c|c|c|c|c|c|}
\hline Decomposition & Fre & stage & Bloa & stage & De & stage & & stage \\
\hline Genus and Species & $\mathrm{n}$ & $\%$ & $\mathrm{n}$ & $\%$ & $\mathrm{n}$ & $\%$ & $\mathrm{n}$ & $\%$ \\
\hline Chrysomya albiceps & 65 & 32.02 & 52 & 17.7 & 15 & 7.7 & 5 & 7.04 \\
\hline Unidentified species & 12 & 6 & 22 & 7.5 & 17 & 8.7 & 2 & 2.8 \\
\hline Unidentified species & 10 & 5 & 25 & 8.5 & 22 & 11.2 & 7 & 10 \\
\hline Sarcophaga carnaria & 43 & 21.1 & 55 & 18.8 & 45 & 23 & 10 & 14.03 \\
\hline Wolhfahrtia & 33 & 16.3 & 45 & 15.4 & 15 & 7.7 & 5 & 7.04 \\
\hline Musca domestica & 25 & 12.3 & 33 & 11.3 & 24 & 7.1 & 15 & 21.1 \\
\hline Dermestes species & 0 & 0 & 3 & 1.02 & 25 & 12.8 & 8 & 11.2 \\
\hline Unidentified species & 5 & 2.5 & 35 & 12 & 13 & 6.6 & 4 & 5.6 \\
\hline Unidentified species & 10 & 5 & 23 & 7.8 & 20 & 10.2 & 15 & 21.1 \\
\hline
\end{tabular}




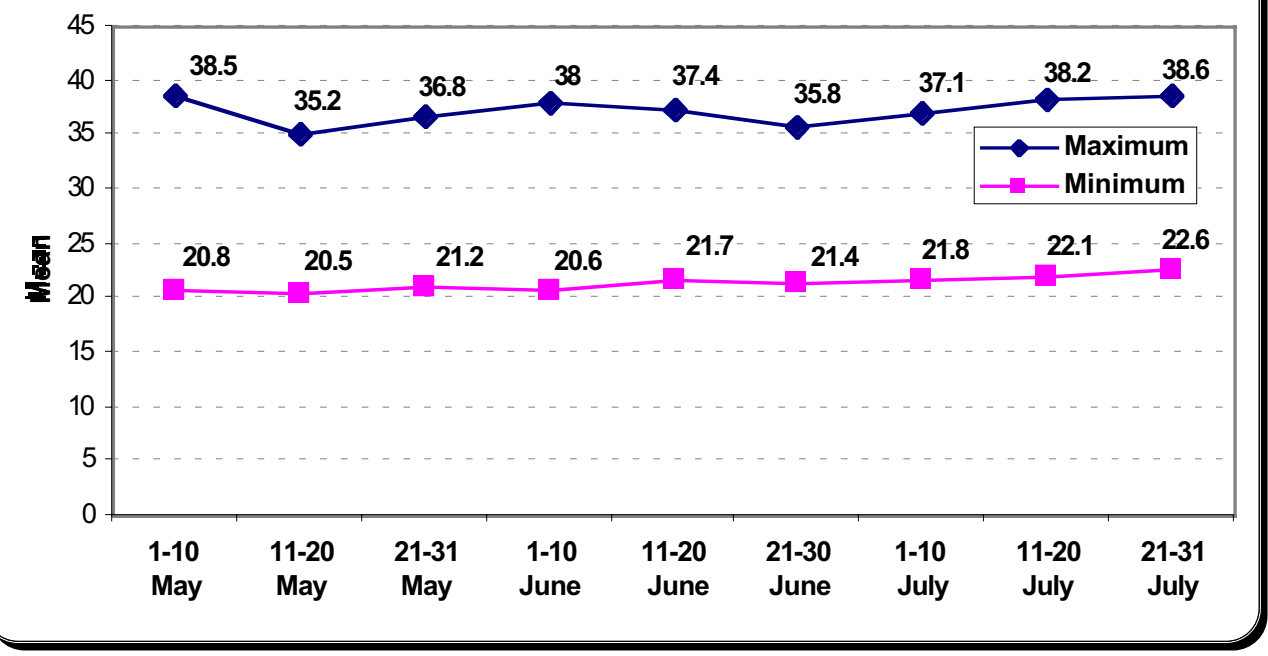

Fig. (1) : Air temperature at Assiut city $\left({ }^{\circ} \mathrm{C}\right)$ during May, June and July months.

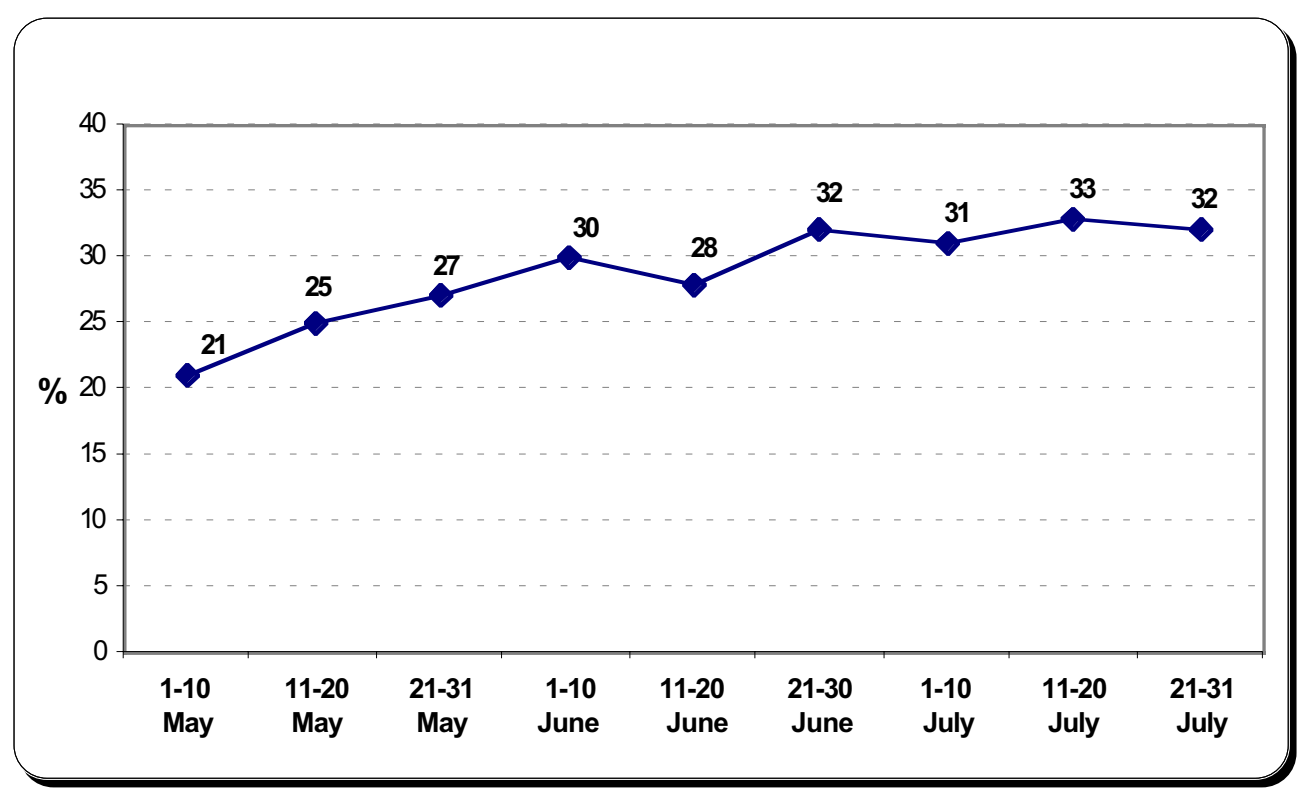

Fig. (2) : Relative humidity (daily \%) in Assiut city during May, June and July months. 


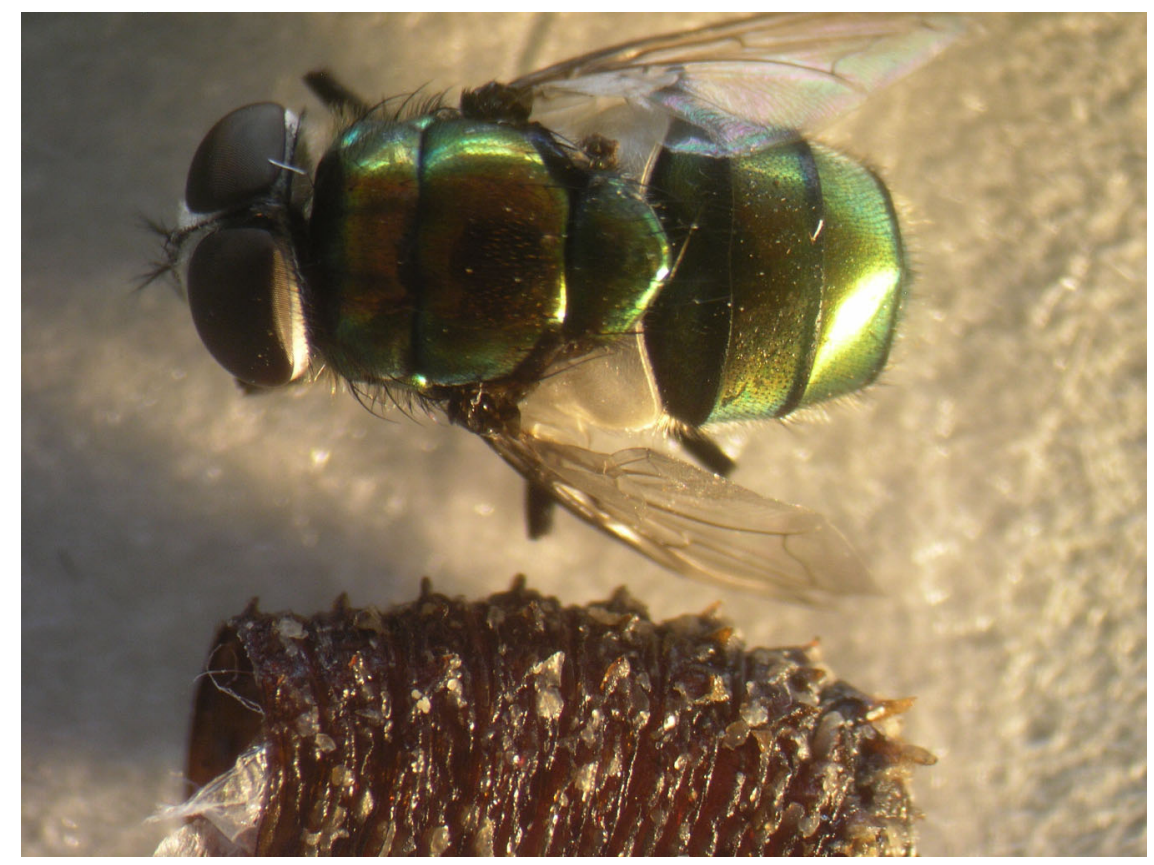

Fig. (3) : A photograph of the adult Chrysoma albiceps and its pupa. 


\section{REFERENCES}

Adham, F. K.; Abdel, M. A.; Tawfik, M. A. and El-Khateeb, R. M. (2001) : "Seasonal incidence of the carrion breeding blowflies Lucilia sericata (Meigen) and Chrysomya albiceps (Wied.) (Diptera: Calliphoridae) in Abu-Rawash Farm, Giza, Egypt". J. Vet. Med., 49:377-383.

Aggarwal, A. D. (2005) : "Estimating the postmortem interval with the help of entomological evidence". AThesis submitted to the Baba Farid University of Health Sciences, Faridkot, 2005 for MD in Forensic Medicine. Anil Aggrawal's Internet Journal of Forensic Medicine and Toxicology, 6 (2): 45-65.

Arnaldos, M. I.; Romera, E.; Presa, J. J.; Luna, A. and Garcia, M. D. (2004) : "Studies on seasonal arthropod succession on carrion in the southeastern Iberian Peninsula". Int. J. Legal Med., 118 : 197205.

Arnaldos, M. I.; Garcia, M. D.; Romera, E.; Presa, J. J. and Luna, A. (2005) : "Estimation of postmortem interval in real cases based on experimentally obtained entomological evidence". Forensic Sci. Int., 149: 57-65.

Attia, R. A. H. (2002) : Studies on some cyclorraphous flies in Assiut Governorate. M.Sc. Thesis, Assiut University.
Bartholo, J.A.; Rocha, F.A.; Rodrigues, P.; Rosa, G.S.; DelBianco Faria, L.; Von Zuben, C.J., Rossi, M.N. and Godoy, W.A. (2002): "Larval dispersal and predation in experimental populations of Chrysomya albiceps and Cochliomyia macellaria (Diptera: Calliphoridae)". Memorias do Instituto Oswaldo Cruz, 97: 1137-1141.

Bharti, M. and Singh, D. (2003) : "Insect faunal succession on decaying rabbit carcasses in Punjab". J. Forensic Sci., 48:1133-1143.

Braack, L. E. (1981) : "Visitation patterns of principle species of the insects'complex at carcasses in the Kruger National Park". Koedoe, 24: 33-49.

Catts, E. P. (1990) : Analyzing data . In: Entomology and Death : A Procedural Guide. Catts, E.P.; Haskell, N.H. (Eds.), Joyce`s Print Shop Inc., Clemson SC, P.P. 124-137.

Centeno, N.; Maldonado, M. and Oliva, A. (2002) : "Seasonal patterns of arthropods occurring on sheltered and unsheltered pig carcasses in Buenos Aires Province (Argentina)". Forensic Sci. Int., 126: 63-70.

Chittaro, Y.; Baylon, A.; Cherix, D. and Wyss, C. (2005) : "What does attract blow flies (diptera, Calliphoridae) in a trap?. Preliminary investigation". Third 
Meeting of European Association for Forensic Entomology, April 27-29; Lausanne, P. 41.

Early, M. and Goff, M. L. (1986) : "Arthropod succession patterns in exposed carrion on the Island of $\mathrm{O}^{\prime}$ hau, Hawaiian Islands, USA". J. Med. Entomol., 23 (5) : 520-531.

Erzinclioglu, Y. Z. (1983) : "The application of entomology to forensic medicine". Med. Sci. Law, 23 (1):57-63.

Erzinclioglu, Y. Z. (1996) : Blowflies. Naturalist Handbook. The Richmond Publishing Co. Ltd, P.P. 33-44.

Fuller, M. E. (1934) : "The insect inhabitants of Carrion : A study in animal ecology". Bulletin of Council Scientific and Industrial Research, Melbourne, 82: 5-62.

Grassberger, M. and Frank, C. (2004) : "Initial study of arthropod succession on pig carrion in central European urban habitat". J. Med. Entomol., 41(3): 511-523.

Greenberg, B. (1971) : Flies and Disease. Vol. (1) Ecology, Classification and Biotic Association. Princepton University Press, Princepton N. J., P.P. 111-121.

Greenberg, B. and Wells, J. D. (1998) : "Forensic use of Megaselia abdita and M. scalaris (Phoridae: Diptera): Case studies, development rates and egg structure". J. Med. Entomol., 35 (3): 205 -209.

Greenberg, B. and Kunich, J. C. (2002) : Entomology and The Law : Flies As Forensic Indicators. $1^{\text {st }}$ ed., Cambridge University Press, Cambridge, P.P. 1-306

Hall, M. J. and Smith, K. G. V. (1993) : Diptera causing myiasis in man. In : Medical Insects and Arachnids. R. P. Lane; R. W. Crosskey (Eds.), Chapman \& Hall, London, P.P. 429-469.

Hanski, I. (1987a) : Nutritional ecology of drug and carrion-feeding insects. In : Nutritional Ecology of Insects, Mites, Spiders, and Related Invertebrates. Sansky, F.; Rodriguez, J.G. (Eds.), Wiley, New York, P.P. 837-884.

Hanski, I. (1987b) : Colonization of ephemeral habitats. In : Colonization, Succession and Stability. Gray, A.J.; Crawley, M. J.; Edwards, P. (Eds.), Blackwell, London, P.P. 155-185.

Hegazi, E. M.; Shaaban, M. A. and Sabry, E. (1991) : "Carrion Insect of the Egyptian western desert". J. Med. Entomol., 28 (5): 734-739.

Hwang, C. and Turner, B. D. (2004) : "Spatial and temporal variability of necrophagous Diptera from urban to rural areas". Med. Vet. Entomol., 18: 308-310. 
Iloba, B. N. and Fawole, S. O. (2006) : "Comparative study of arthropod fauna on exposed carrion across the vertebrate classes". Inter. J. Biomed. Health. Sci., 2 (2):51-65.

Introna, F. and Campobasso, C. P. (2000) : Forensic dipterology. In : General and Applied Dipterology. Papp, L.; Darvas, B. (Eds.), Science Herald, Budapest, P.P. 793-846.

Larsen, T. B. (1989) : The Butterflies of Egypt : The Distribution of Butterflies Within Egypt". 1 ${ }^{\text {st }}$ ed., Apollo Books, Svendborg, P.P. 80-98.

Lee, H. L.; Krishnasamy, M.; Abdullah, A. G. and Jeffrey, J. (2004) : "Review of forensically important entomological specimens in the period of 1972-2002". Trop. Biomed., 21 (2): 69-75.

Lord, W. D. and Burger, J. F. (1984) : "Arthropods associated with herring gulls (Larus argentatus) and great black-backed gulls (Larus marinus) carrion on islands in the gulf of Maine". Environ. Entomol., 13: 1261-1268.

Macleod, J. and Donelly, J. (1963) : "Dispersal and interspersal of blow fly populations". J. Anim. Ecol., 31 : 1 32.

Marchenko, M. I. (2001) : "Medicolegal relevance of cadaver entomofauna for the determination of the time of death". Forensic Sci. Int., 120: 89-109.

Moatamed, A. (2005) : "Ecosystems and its problems in Assiut governorate: A study in applied geography". PhD. Thesis, Assiut University.

Mosallam, S. S. (1980) : "Biological studies of some myiasis producing dipterous flies in Cairo". Ph.D. Thesis, Ain Shams University, Cairo.

Nuorteva, P. (1977) : Sarcosaprophagous insects as forensic indicators. In : Forensic Medicine : A Study in Trauma and Environmental Hazards. Tedeschi, C. G.; Eckert, W. G., Tedeschi, L. G. (Eds.), Vol. II, W. B. Saunders Company, Philadelphia, P.P. 1072-1095.

O'Flynn, M. A. and Moorhouse, D. E. (1979): "Species of Chrysomya as Primary Flies in Carrion". J. Aust. Entomol. Soc., 18: 31-32.

Omar, A. H. (1995) : "Cannibalism and predation behaviour of the blowfly, Chrysomyia albiceps (Wiedemann) larvae (Diptera Calliphoridae)". J. Egypt Soc. Parasitol., 25: 729-743.

Payne, J. A. (1965) : "A summer carrion study of the baby pig sus scrofa linnaeus". Ecology, 46 (5): 592-602. 
Reed, H. B. (1958) : "A study of dog carcass communities in Tennessee with special reference to the insects". Am. Midl. Nat., 59: 213-245.

Rodriguez, W. C. and Bass, W. M. (1983) : "Insect activity and its relation ships to decay rates of human cadavers in east Tennesse". J. Forensic Sci., 28:423-432.

Schoenly, K. and Reid, W. (1987) : "Dynamics of heterotrophic succession in carrion arthropod assemblages: discrete series or a continuum of change". Oecologia, 73: 192-202.

Schoenlly, K.; Goff, M. L.; Wells, J. D. and Lord, W. D. (1996) : "Quantifying statistical uncertainty in succession- based entomological estimates of the postmortem interval in death scene investigations: a simulating study". Am. Entomol., 42: 106-112.

Shaumar, N. F.; Mohamed, S. K. and Mohamed, S. A. (1989) : "Keys for identification of species of family Calliphoridae (Diptera) in Egypt". J. Egypt. Soc. Parasitol., 19(2):669-681.

Tabor, K. L.; Fell, R. D. and Brewster, C. C. (2005) : "Insect fauna visiting carrion in Southwest Virginia". Forensic Sci. Int., 150: 73-80.
Tantawi, T. I.; El-kady, E. M.; Greenberg, B. and El-Ghaffar, H. A. (1996) : "Arthropod succession on exposed rabbit carrion in Alexandria, Egypt". J. Med. Entmol., 33: 566-590.

Tomberlin, J. K. and Adler, P. H. (1988) : "Seasonal colonization and decomposition of rat carrion in water on land in an opened field in South Carolina". J. Med. Entomol., 35(5): 704-709.

Tullis, K. and Goff, M. L. (1987) : "Arthropod succession in exposed carrion in a tropical rainforest on $\mathrm{O}^{\prime}$ hau island, Hawaii". J. Med. Entomol., 24 : 332339.

Turchetto, M. and Vanin, S. (2004) : "Forensic entomology and climatic change". Forensic Sci. Int., 146 Suppl : 207209.

Von Aesh, L.; Pellet, J.; Cherix, D. and Wyss, C. (2003) : "Activity and behaviour of blow flies on pig liver baits in spring". Bull. Soc. Entomol. Suisse., 76 : 201-206.

Wells, J. D.; Byrd, J. H. and Tantawi, T. I. (1999) : "Key to third-instar Chrysomyinae (Diptera:Calliphoridae) from carrion in the Continental United States". J. Med. Entomol., 36 (5): 638-641. 


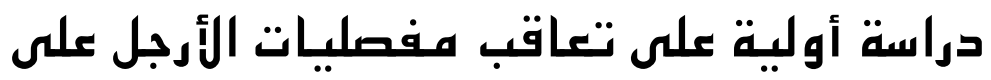

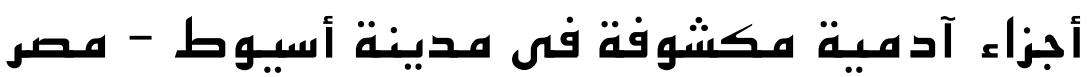

$$
\text { المشتركون فى البحث }
$$

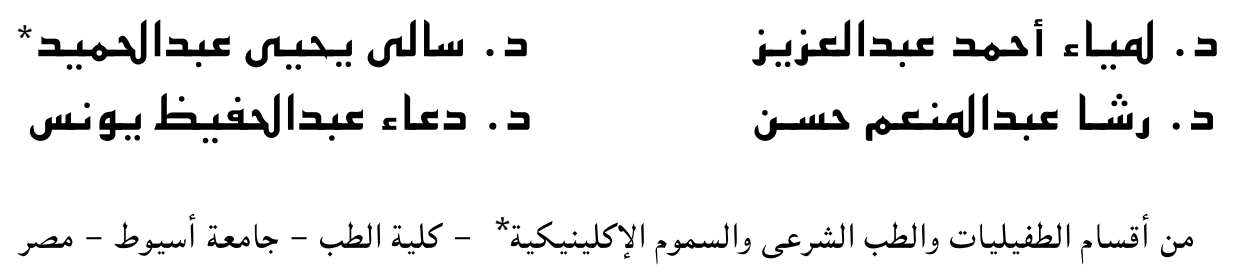

علم الحشرات الجنائى يستخدم مراحل النمو المختلفة للحشرات المفصلية كدليل حشرى فى موقع الجريمة لتقدير الفترة التى مضت على الوفاة وذلك باستخدام موجات التعاقب أو عمر الدودة وتطور نموها ، فأنماط تعاقب الحشرات المفصلية تتأثر كثيراً بدرجة الحرارة والرطوبة وتختلف الحشرات من الناحية الوظيفية ومعدل النمو تبعاً لموقعها الجغرافى، لذلك معرفة الحشرات السائدة فى كل موقع جغرافى يكون مفيداً فى حالات التحقيقات الجنائية، حيث أن أى معلومات عن الحشرات من منطقة أخرى سيكون لها خصائص بيئية ووظيفية مختلفة قد تؤدى إلى درجة غير كافية من الدقة، والهدف من هذا البحث تسجيل أنواع الحشرات المفصلية وحركة تعاقبها بالنسبة إلى مراحل التفسخ المختلفة للأجزاء الآدمية المستأصلة المكشـوفة بمدينة أسيوط بمصر أثناء فصلى الربيع والصيف. أجرى البحث على أجزاء آدمية مستـأصلة من عمليـات جراحية وتم تعريضها للهواء بوضعها فى صندوق به أرضية ترابية على سطح كلية الطب بجامعة أسيوط، تم فحص العينات لملاحظة مراحل التفسخ وتجميع الحشرات الطائرة والزاحفة واليرقات لفحصها وتحديد فصائلها، وتم تربية الحشرات غير كاملة النمو فى المعمل للوصول للحشرة الناضجة لفحصها ـ أسفرت النتائج عن وجود العديد من الحشرات التى تم ربط ظهورها بمراحل التفسخ المختلفة، تم التعرف على العديد من الحشرات ومنها ماينتمى للحشرات ثنائية الأجنحة (ذباب حقيقى) ويتضمن (الذباب الأخضر، ذبابة اللحم ، الذباب ماسكيدى) والحشرات محميات الأجنحة (الحنافس) وغشائيات الأجنحة كالنمل. أظهر التوثيق الأولى للحشرات فى مدينة أسيوط ذات الطبيعة الحضرية القحلة أن الحشرات ثنائية الأجنحة كانت السائدة يتبعها الحشرات محميات الأجنحة وإن الذباب الأخضر لم يتواجد بكثرة كما كان متوقع ووجد أن حشرة الكريسوما البيسبس كانت الحشرة السائدة من خلال الدراسة. 